\title{
EFFICIENCY AND COMPETITIVENESS OF BANK PERKREDITAN RAKYAT (BPR) IN THE BALI PROVINCE OF INDONESIA
}

\author{
Layyinaturrobaniyah \\ Fakultas Ekonomi dan Bisnis, Universitas Padjajaran \\ layyinaturrobaniyah@unpad.ac.id \\ Mokhamad Anwar \\ Fakultas Ekonomi dan Bisnis, Universitas Padjajaran \\ Ratna Komara \\ Fakultas Ekonomi dan Bisnis, Universitas Padjajaran \\ Sulaeman R. Nidar \\ Fakultas Ekonomi dan Bisnis, Universitas Padjajaran
}

\begin{abstract}
This study aims to estimate and test technical efficiency and conduct analysis on the competitiveness of BPRs in the Province of Bali for the period 2012-2016. Estimation on efficiency with the Data Envelopment Analysis (DEA) method was carried out on 134 BPRs whose data is obtained from OJK Regional Office 8 Bali and Nusa Tenggara. Meanwhile, to analyze competitiveness, a questionnaire was distributed to BPR customers, upon which data from customers is analyzed by Focus Group Discussion (FGD) together with BPR and OJK management as regulators. The Results of this study showed that in average, the technical efficiency of BPRs in Bali decreased from year to year from, i.e., 0.6581 in 2012 to 0.5993 in 2016. Buleleng Regency is listed as an area that has the most efficient BPRs with an average efficiency value of 0.7575, then followed BPRs from Karangasem Regency in second place with efficiency scores of 0.7184, and BPRs from Gianyar Regency in third place with a score of 0.6854. Further, based on the results of the analysis of competitiveness and from the FGD, it can be concluded that one of the strengths of BPRs in Bali Province is the loyalty of its customers.
\end{abstract}

Keywords: data envelopment analysis, technical efficiency, competitiveness, BPR performance.

\begin{abstract}
Abstrak
Penelitian ini bertujuan untuk mengestimasi dan menguji efisiensi teknis serta melakukan analisis mengenai daya saing dari bank-bank BPR di Provinsi Bali untuk periode 2012-2016. Estimasi dan analisis mengenai efisiensi dengan metode Data Envelopment Analysis (DEA) dilakukan pada 134 BPR yang datanya diperoleh dari Kantor Regional 8 OJK Bali dan Nusa Tenggara. Sementara itu, untuk menganalisis daya saing, kuesioner dibagikan kepada pelanggan BPR, data dari pelanggan dianalisis oleh Focus Group Discussion (FGD) bersama dengan manajemen BPR dan OJK sebagai regulator. Hasil penelitian ini menunjukkan bahwa secara rata-rata, technical efficiency BPR di Bali menurun dari tahun ke tahun, yaitu dari 0,6581 pada 2012 menjadi 0,5993 pada 2016. Kabupaten Buleleng terdaftar sebagai daerah yang memiliki BPR paling efisien dengan rata-rata nilai efisiensi 0,7575, kemudian diikuti BPR dari Kabupaten Karangasem di tempat kedua dengan skor efisiensi 0,7184, dan BPR dari Kabupaten Gianyar di tempat ketiga dengan skor 0,6854. Selanjutnya, berdasarkan hasil analisis daya saing dan dari FGD, dapat disimpulkan bahwa salah satu kekuatan BPR di
\end{abstract}


Provinsi Bali adalah kesetiaan pelanggannya.

Kata Kunci: data envelopment analysis, efisiensi teknik, daya saing, kinerja BPR. JEL: C80

\section{Research Background}

Banking competition in Indonesia, especially for the small micro business segment, is getting tougher. Bank Perkreditan Rakyats (BPRs) over the past few decades have been considered to be very superior in providing micro and small financing throughout Indonesia. The development of People's Credit Banks (BPR) during the decade of the 2000s has grown rapidly to 1,700 banks. However, the number of BPRs is currently decreasing to around 1,619 BPR in 2018 spread across various provinces, including Bali Province (Infobank 2018). The continuous decline in the number of BPRs is caused by various things. Several reasons that are suspected as the cause of the decline in the number of BPRs in the last 5 years have mainly included: lower interest rates, many commercial banks that enter the micro and small business segment, and the emergence of financial technology that replaces the role of banks, especially those that function as financial intermediaries.

The low interest rates initiated by the Indonesian Government through regulations carried out by Bank Indonesia (BI) caused deposits and interest rates to be very small compared to a few decades ago. Based on a report from Bank Indonesia (Bank Indonesia Report 20122016), the BI rates during the research observation period ranged from 5.75\% in February 2012 to $6.5 \%$ in July 2016. In addition, the existence of program loans through the Kredit Usaha Rakyat Scheme (KUR) with very low interest rates (from 21\% in 2015 to $12 \%$ in 2016 and $9 \%$ in 2017) has caused the transfer of borrowers from BPR to commercial banks implementing KUR. This situation forces BPRs to always innovate products and provide excellent services even though the interest rates offered are still quite high.

It is true that the existence of a low interest rate policy provided by commercial banks will benefit customers because credit costs are cheaper. However, for BPRs, if the market interest rates are too low, then the market share of BPRs will be increasingly eroded, because borrowers in BPRs will move to commercial banks on the ground of interest rates. This situation will also make difficult for BPRs to find new debtors because the interest rates offered are higher. Nevertheless there are some loyal customers who not only consider interest rates, but they also see the comfort and closeness of BPRs personnel as their reason to remain a customer of BPRs.

The presence of commercial banks that have entered the micro and small business sector in recent years has also increased the climate of competition with commercial banks in the segment. Indeed, commercial banks must comply with regulations mandated by Bank Indonesia Regulation (PBI No. 14/22 / PBI / 2012 concerning Financing Micro, Small and Medium Enterprises (MSMEs) and MSME Technical Assistance. In accordance with these regulations commercial banks is required to provide financing to MSMEs at a certain percentage in stages until the end of 2018, where the MSME credit position of each commercial bank must reach a minimum of $20 \%$ of the total loans disbursed.

The presence of commercial banks that have entered the micro and small business sector in recent years has also increased the climate of competition with commercial banks in the segment. Indeed, commercial banks must comply with regulations mandated by Bank Indonesia Regulations (PBI No. 14/22 / PBI / 2012 concerning financing of for micro and small businesses and technical assistance of UMKM. In accordance with these regulations commercial banks is required to provide financing to UMKM at a certain percentage in stages until the end of 2018, where the MSME credit position of each commercial bank must reach a minimum of $20 \%$ of the total loans disbursed. 
The development of financial technology has also developed very rapidly, especially with the pattern of peer to peer lending which can replace the function of banks as financial intermediaries. In the current digital era, the use of financial technology is needed to accelerate services and operational efficiency of transactions between parties. The presence of financial technology not only eroded the BPR credit market, but also reduced the market share of commercial banks, especially loans for micro and small businesses in Indonesia.

Based on the conditions as mentioned above, it is interesting to evaluate the performance of rural banks in terms of technical efficiency and competitiveness in the era of highly competitive competition in the banking industry. The technical efficiency of banks is believed to be a strong foundation for BPRs to survive in the current era. The presence of BPRs is certainly expected to always support economic development in this region. This research is very important to do because of three reasons. First, this research is the first study to estimate the technical efficiency of BPRs in Bali Province where Bali is one of the provinces that have a large number of BPRs with good performance (Infobank 2018). Second, this study outlines and compares the performance of BPRs based on districts and different ownership. Third, out of several factors at BPRs in this study, the following factors will be analyzed which can be a competitiveness for BPRs in Bali Province using SWOT analysis.

This condition may not be a big problem for commercial banks, considering that they have a fund deposit structure that varies from current accounts, savings and time deposits. However, what about BPR? If BPR receives deposits with high funding costs and high net interest margin (NIM), of course BPR will offer a high credit interest rate.

The customer who keeps his money at the BPR is certainly based on high trust in the institution, in this case it is expected that there will be no difficulty if one day the customer wants to withdraw his/her money. In addition, if the customer wants to get credit, he/she wants the process to be faster, the requirements to be simple and the institution to be very understanding of the needs of the customer. BPR is an institution that sells trust. In order to maintain public confidence, the government made various regulations related to BPR. OJK understands that the role of BPRs that serve the lower classes and has helped develop the local economy since long ago, needs to be maintained. For this reason, in order to make BPR industry strong and has competitiveness. The FSA has issued a number of new rules for the BPR industry. The OJK seeks to improve the weaknesses of BPR which are considered to hinder the development of BPR.

In order to increase competitiveness of BPR, it must increase efficiency. Efficiency is basically one of the parameters of banking performance, BPRs whose operational activities are not in accordance with the capacity that is owned or operating under the economies of scale can cause BPRs to be inefficient. In addition, to improve the competitiveness of BPRs, their environment needs to be identified, in this case the micro and macro environment.

\subsection{BPR Efficiency}

Research on efficiency begins with Farrel's (1957) research with a frontier concept where if a company is compared to similar companies, there will be companies that are in an efficient condition or the companies are on the frontier curve. This concept was further developed by Shephard (1970) and Afriat (1972) where they used deterministic method through mathematical programming to estimate the frontier. Then, finally Charnes, Cooper and Rhodes (1978) introduced data envelopment analysis (DEA) which until now has been widely used by researchers in estimating efficiency with a deterministic (non-parametric) approach. In addition to deterministic methods, efficiency estimation can also be done with the stochastic or parametric method by including inefficiencies and term-error elements in estimates. In this parametric or stochastic flow, there is a very popular method known as Stochastic Frontier Analysis (SFA). Specifically, for the analysis in this article, estimation of technical efficiency is carried out using the DEA approach which is part of the non-parametric. 
Research on efficiency in the banking industry has been carried out by many authors in various countries in the world (see the survey conducted by Berger and Humphrey (1997), also Fethi et al. (2011)). They generally conducted research on the objects of commercial banks considering that commercial banks are the most widely used banks in the banking industry throughout the world. Meanwhile, research carried out for BPR is still very rare.

In conducting research on bank efficiency, there are several estimation models that can be used such as technical efficiency, cost efficiency and profit efficiency. This research focuses on technical efficiency to see the operational side of the banking system as a whole seen from the use of resources (inputs), namely deposits, general and administrative costs, and fixed assets in serving customers to produce output in the form of loans and operating profit earned.

Many research has been carried out on efficiency in the context of commercial banks. The research of this study uses Data Envelopment Analysis (DEA) and those related to this study include: Fethi et al. (2011), Sufian (2010), Gardener et al. (2011), Haddad et al. (2011), Suzuki and Sastrosuwito (2011), and Anwar (2015).

Meanwhile, research that estimates the efficiency and competitiveness of BPRs in particular is still very limited to date. One study found in the context of BPR is Nashihina and Harahap (2014). They have conducted research by comparing the results of efficiency using stochastic frontier analysis (SFA) and financial ratio analysis for rural banks in Indonesia. The results show that the average efficiency of BPR is at a good level of around $90 \%$ and the results of BPR financial ratios are in line with the results of efficiency estimated using SFA.

In addition, several studies on the efficiency of BPR have been carried out in other developing countries. Lamberte and Desrocher (2002) who examined the relationship between cooperative BPR efficiency and corporate governance in the allocation of agency costs in the Philippines. They found that agency costs significantly reduced the cost efficiency of cooperative rural BPRs and the most efficient BPRs had better control over agency costs. Then, Jayamaha (2012) examined the efficiency of rural BPRs in Sri Lanka. They found that there were significant differences in the efficiency of BPRs that were tested based on geographical location and that there was a positive relationship between the size of BPR and bank efficiency. Adusei (2016) studied the determinants of BPR technical efficiency in Ghana. The findings show that bank size, profitability, and funding quality are factors that significantly determine technical efficiency in the BPR industry in Ghana.

\subsection{BPR Competitiveness}

Companies that do not have competitiveness will be abandoned by the market. Because they not having competitiveness means not having excellence, and not being superior. It means there is no reason for a company to survive in the competitive market for the long term. Competitiveness relates to the effectiveness of a company in competition, compared to other organizations that offer the same or similar products or services. Companies that are able to produce good quality products or services are companies that are effective in the sense that they will be able to compete.

Porter (1980) says that competition is the core of a company's success or failure. There are two sides caused by competition, namely the success side because it encourages companies to be more dynamic and compete in producing and providing the best service for their markets, so that competition is seen as a motivating opportunity. While the other side is failure because it will weaken companies that are static, afraid of competition and unable to produce the best quality of products, so competition is a threat to the company.

According to Muhardi (2007) operating competitiveness is an operating function that is oriented not only internally but also externally, which proactively responds to the target market of its business. The dimensions of a company's competitiveness as stated by Muhardi (2007) by quoting Ward et al. (1998) are composed of cost, quality, delivery time, and flexibility.

Competitiveness requires resources that can be distinctive competencies which are 
unique strengths that enable companies to achieve superior efficiency, quality and innovation to create value creation and competitive advantage (Hill and Jones 2010). The idea of resources based view (RBV) according to Pearce and Robinson (2015) states that each company is different in terms of its fundamentals because each company has a unique collection of resources consisting of tangible assets, intangible assets, and capabilities organization to utilize these assets. Tangible assets are easily identifiable assets, which are often found in company balance sheets, for example: production facilities, raw materials, financial resources, real estate, and computer aircraft. Intangible assets are corporate assets that cannot be touched and cannot be seen but are very important for the creation of competitive advantages, such as: brand name, company reputation, organizational morale, technical knowledge, patents and trademarks, and accumulated organizational experience. An organizational capability is a skill or the ability on how to combine assets, people, and processes to convert inputs into outputs. Furthermore, it was revealed that valuable organizational resources have valuable characteristics, namely: rare, difficult to imitate, ability to exploit. A valuable resource is one that can be used to exploit external conditions that can provide income for the organization or neutralize unfavorable external factors. Rare resources are competencies or privileges that competitors do not have, for example resources those are hard to imitate, either by substitution or duplication. The company must have the ability to exploit it.

\section{Tabel 1. Recapitulation of the Concepts of the Strength of the Industrial Environment}

\begin{tabular}{|c|c|c|}
\hline No & Author & Concept \\
\hline 1 & $\begin{array}{l}\text { Kotler and Keller } \\
\text { (2012) }\end{array}$ & $\begin{array}{c}\text { The business environment consists of the internal environment and the externa } \\
\text { environment of the company that influences the formulation of business } \\
\text { strategies in an effort to improve business performance. }\end{array}$ \\
\hline 2 & $\begin{array}{l}\text { Wheelen et al. } \\
\text { (2015) }\end{array}$ & $\begin{array}{l}\text { The level of competition in industry is determined by basic competitive forces } \\
\text { that determine the highest potential profit that can be achieved in an industry } \\
\text { where the potential profit is measured by long-term returns of invested capital. }\end{array}$ \\
\hline 3 & $\begin{array}{c}\text { Thompson et al. } \\
\text { (2014) }\end{array}$ & $\begin{array}{c}\text { Competition pressure on companies in an industry comes from five strengths, } \\
\text { namely: competition between competitors, competition with new entrants, } \\
\text { competition with producers or substitute products, bargaining power of } \\
\text { suppliers and bargaining power of customers. }\end{array}$ \\
\hline 4 & Hitt et al. (2015) & $\begin{array}{l}\text { To study an industry, companies test five forces that influence the ability of all } \\
\text { companies to gain profits in the industry. The five competitive forces are: the } \\
\text { threat of new entrants, supplier strength, buyer strength, substitute products, } \\
\text { the intensity of competition among competitors. }\end{array}$ \\
\hline 5 & $\begin{array}{c}\text { Pearce and } \\
\text { Robinson (2015) }\end{array}$ & $\begin{array}{l}\text { The strength of competition that determines the profitability of an industry is } \\
\text { the most important thing in the formulation of strategies. There are five } \\
\text { strengths of the industrial environment that affect the company: the threat of } \\
\text { new entrants, the strength of suppliers (suppliers), the strength of buyers, the } \\
\text { threat of substitution, competition between industry players. }\end{array}$ \\
\hline 6 & $\begin{array}{l}\text { Porter (1980) in } \\
\text { Hoque and Chia } \\
\text { (2012) }\end{array}$ & $\begin{array}{c}\text { Five industrial competition forces: threat of potential entrants, bargaining } \\
\text { power of buyers, substitutes products or services, bargaining power of } \\
\text { suppliers, and the rivalry among existing firms. }\end{array}$ \\
\hline
\end{tabular}

On the basis of the recapitulation of the above concepts and the exploration from previous research journals, the definition of banking industry company resources is a series of assets owned by the company in creating superior value for the customer, where the asset focuses on tangible assets, intangible assets and supported by organizational ownership having high capability, both in terms of competency and organizational commitment in creating superior performance. 
The determination of the construct of the definition of company resources is adjusted to the banking analysis unit in this case of rural bank in accordance with the general conditions faced by BPR in Bali Province which have weaknesses in company resources which are thought to result in fluctuating and not optimal business.

\subsection{SWOT Analysis}

According to Rangkuti (2006) SWOT analysis is an analysis based on logic that can maximize strengths and opportunities, but simultaneously can minimize weaknesses and threats. This technique aims to determine realistic business, in accordance with the conditions of the company and therefore more easily achieved by each company.

The following is an explanation of SWOT according to David (2013), namely:

\subsubsection{Strength}

Strength is the resources, skills, or other advantages that relate to the company's competitors and the market needs that can be served by the company that is expected to be served. Strength is a special competence that provides a competitive advantage for companies in the market.

\subsubsection{Weakness}

Weaknesses are limitations or shortcomings in resources, skills, and capabilities that effectively hinder a company's performance. These limitations can be in the form of facilities, financial resources, management capabilities and marketing skills. They can be a source of company weaknesses.

\subsubsection{Opportunities}

Opportunities are important situations that are beneficial in the corporate environment. Important trends are one source of opportunity, such as technological change and the increasing relationship between companies and buyers or suppliers. They are examples of opportunity for companies.

\subsubsection{Threats}

Threats are important situations that are not profitable in the corporate environment. Threats are the main intruder for the current position or desired by the company. The existence of new or revised government regulations can be a threat to the company's success.

\section{Research Method}

To estimate the technical efficiency of BPR, this study uses secondary data from 134 BPR financial statements operating in 7 districts in the Bali Province within 5-year period, from 2012 to 2016. According to the composition, 134 banks including 3 government-owned banks and 131 privately owned BPRs. Data is collected from OJK Regional Office for Bali and Nusa Tenggara.

In addition, to conduct a competitiveness model analysis a primary data collection process was also carried out by distributing questionnaires to BPR customers. The questionnaire was distributed to the most efficient customers of several BPRs in 3 years, namely BPR Indra Candra (Best BPR with assets of 500Bilion to 1Trilion rupiahs), BPR Pande Artha Dewata, BPR Lestari, BPR Artha Bali Jaya, and BPR Sukowati Pancakanti. The total respondents obtained from the process of distributing the questionnaire were 127 respondents.

To strengthen and deepen the analysis of the results of questionnaires, Focus Group Discussion activities were also conducted with the management of several efficient BPRs in Bali and the OJK as the regulator so that BPR competitiveness models could be formulated using SWOT analysis. 
The population in this study was 134 rural banks operating in 7 districts in the Province of Bali. Meanwhile, the sampling technique uses purposive sampling with the following criteria: 1) banks are rural banks in the area of OJK Bandung regional office supervision, 2) bank data must be complete during the observation period, namely the period $2012-2016$.

The variable to be analyzed in this study is the technical efficiency of BPR estimated by the Data Envelopment Analysis (DEA) method, while the BPR competitiveness variable will be analyzed using a SWOT analysis.

In estimating the efficiency of BPR, this study uses data envelopment (DEA) analysis method assuming the variable return to scale (VRS) and determining input-output data using the intermediation approach. The outputs are loans and operating income. While the inputs are deposits, general and administrative costs, and fixed assets.

This study uses DEA with model specifications as follows: 1) research uses an intermediation approach in determining input and output. Thus, deposits have been considered and included as one of the inputs together with net fixed assets, as well as general and administrative costs; in addition, this study uses loans, placements, and operating income as output; 2) Research uses the assumption of variable return to scale (VRS) as one of the bases in estimating efficiency.

Meanwhile, to carry out an analysis of BPR competitiveness, questionnaires were distributed to customers of BPRs that were included in the technically efficient category and then conducted a Focus Group Discussion with BPR and OJK management as regulators so that BPR competitiveness models could be formulated using SWOT analysis.

\section{Result and Discussion}

\subsection{Average Value of Technical Efficiency of Rural Banks in Bali Province}

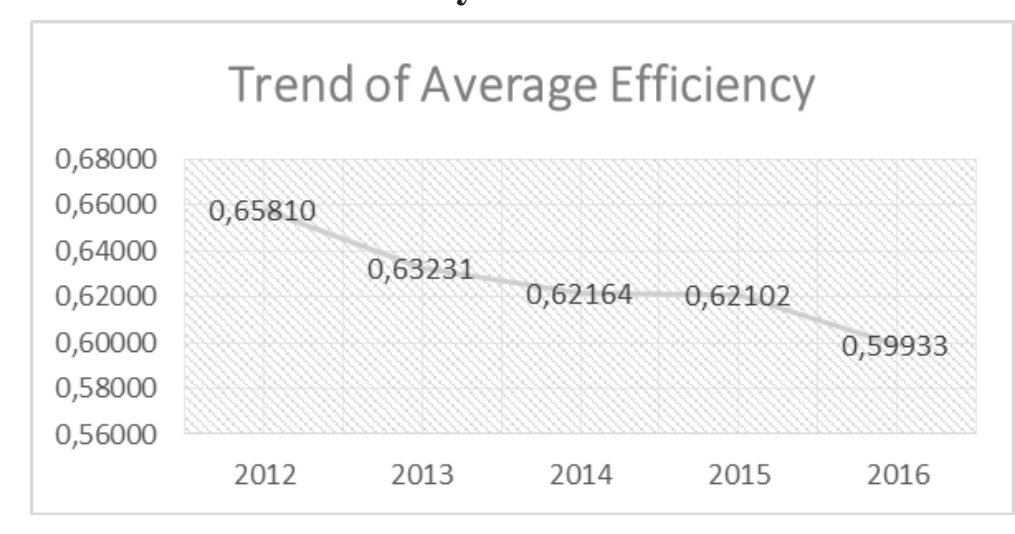

Figure 1. Average Trend of Efficiency of Rural Banks in Bali

Source: Data processed, 2018.

On average, the technical efficiency of BPR banks in Bali has decreased from year to year from the figure of 0.6581 in 2012 to 0.5993 in 2016. Indeed banking competition in 20122016 is quite strict especially for the micro and small sectors which are characterized by micro business credit scheme (KUR) through its low-interest implementing banks. In addition, commercial banks are required to provide a percentage of their loan portfolio in stages until the end of 2018, 20\% of the total outstanding loans must be available to micro and small enterprises (MSMEs) as mandated Bank Indonesia Regulation No. 14/22 / PBI / 2012 dated 21 December 2012 concerning Provision of Credit or Financing and Technical Assistance in the context of the Development of Micro, Small and Medium Enterprises. In addition, there has been a rapid development of financial technology (fintech) which also if it is not anticipated by increasing the quality of digital technology services from BPRs, then BPRs will be outdated and abandoned by their customers.

However, although in general the efficiency level of BPR decreased on average during 
the study period, there were some that were technically at the frontier (efficient) for several years of the study period. In fact there were 6 efficient BPRs for 5 consecutive years. By region (Zoning) based on District / City level (Districts), there are banks that in certain regions on average obtain quite good efficiency rates, as seen in Figure 2. Buleleng Regency is listed as the region that has the most efficient BPRs with an average efficiency value of 0.7575 , then followed by BPR banks from Karangasem Regency in the second position with an efficiency score of 0.7184 , and BPRs from Gianyar Regency in third place with a score of 0.6854 .

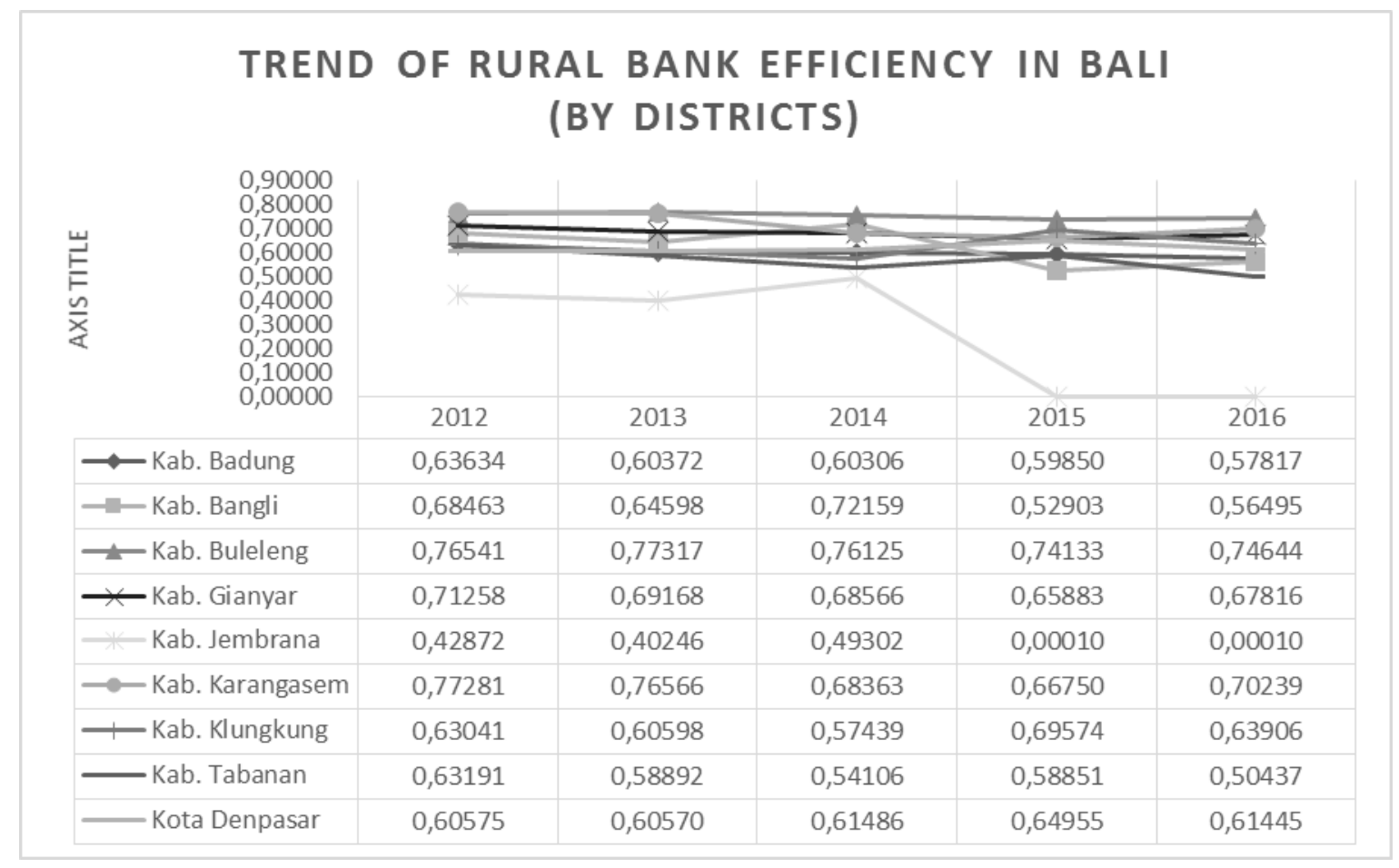

Figure 2. Trend of Efficiency of Rural Banks by Regency / City Area in

Source: Data processed, 2018.

Based on its development over time during the study period, as shown in Figure 2, it can be seen that on average the BPR banks in Bali experienced a downward trend except Klungkung and Denpasar Regencies. Although Buleleng Regency has decreased, it is still at the highest level of efficiency

Tabel 2. Average Ranking of Efficiency by Regency / City

\begin{tabular}{ccccc}
\hline No & District & Average & Rank & Observations \\
\hline 1 & Kab. Badung & 0.60396 & 7 & 51 \\
2 & Kab. Bangli & 0.62924 & 6 & 3 \\
3 & Kab. Buleleng & 0.75752 & 1 & 7 \\
4 & Kab. Gianyar & 0.68538 & 3 & 27 \\
5 & Kab. Jembrana & 0.26488 & 9 & 1 \\
6 & Kab. Karangasem & 0.71840 & 2 & 4 \\
7 & Kab. Klungkung & 0.62911 & 4 & 5 \\
8 & Kab. Tabanan & 0.57096 & 8 & 23 \\
9 & Kota Denpasar & 0.61806 & 5 & 13 \\
& & & TOTAL & 134
\end{tabular}

Source: data processed, 2018 
Table 2 describes the average efficiency achieved by BPR banks by Regency / City region with the number of banks or number of observations for each region. The regencies of Badung, Gianyar, and Tabanan have the highest number of BPR compared to other regions.

Table 3. Efficient BPR Bank Names in Bali (3-5 Years)

\begin{tabular}{cccc}
\hline No & Name of Rural Bank & Districts & Description \\
\hline 1 & PT. BPR Indra Candra d/h MAI BP Indra & Kab. Buleleng & 5 times efficient (5 year) \\
2 & PT. BPR Sri Artha Lestari & Kota Denpasar & 5 times efficient (5 year) \\
3 & PT. BPR Jaya Kerti & Kab. Badung & 5 times efficient (5 year) \\
4 & PT. BPR Padma & Kota Denpasar & 5 times efficient (5 year) \\
5 & PT. BPR Suryajaya Kubutambahan & Kab. Buleleng & 5 times efficient (5 year) \\
6 & PT. BPR Danamaster Dewata & Kab. & 5 times efficient (5 year) \\
7 & PT. BPR Artha Bali Jaya & Karangasem & \\
8 & PT. BPR Artha Rengganis & Kab. & 4 times efficient (4 year) \\
9 & PT. BPR Bali Artha Anugrah & Klungkung & \\
10 & PT. BPR Ayunulus & Kab. Tabanan & 4 times efficient (4 year) \\
11 & PT. BPR Mambal & Kab. Badung & 3 times efficient (3 year) \\
12 & PT. BPR Kita Centradana & Kab. Badung & 3 times efficient (3 year) \\
13 & PT. BPR Dewangga Bali Artha & Kab. Badung & 3 times efficient (3 year) \\
\hline
\end{tabular}

Source: Data processed, 2018.

Table 3 describes the names of efficient BPR banks for 3-5 times during the study period (2012-2016). There are 6 banks that have 5 or 5 consecutive years operating efficiently, namely Bank BPR Indra Chandra, BPR Sri Artha Lestari, BPR Jaya Kerti, BPR Padma, BPR Suryajaya Kubutambahan, and BPR Danamaster Dewata. Of the six efficient banks continuously for 5 years, two BPRs came from Buleleng Regency, two BPRs from Denpasar City, one from Kab. Badung, and one from Karangasem.

\subsection{Competitiveness of Rural Banks in the Province of Bali}

Based on the results of questionnaires, distributed to the customers of several BPRs, the most effienct BPRs in Bali Province are BPR Indra Candra (Best BPR with assets of 500Bilion to 1Trilion rupiahs), BPR Pande Artha Dewata, BPR Lestari, BPR Artha Bali Jaya, and BPR Sukowati Pancakanti. The total respondents obtained from the process of distributing the questionnaire were 127 respondents. The following is the profile of respondents from several BPRs in the Province of Bali. 


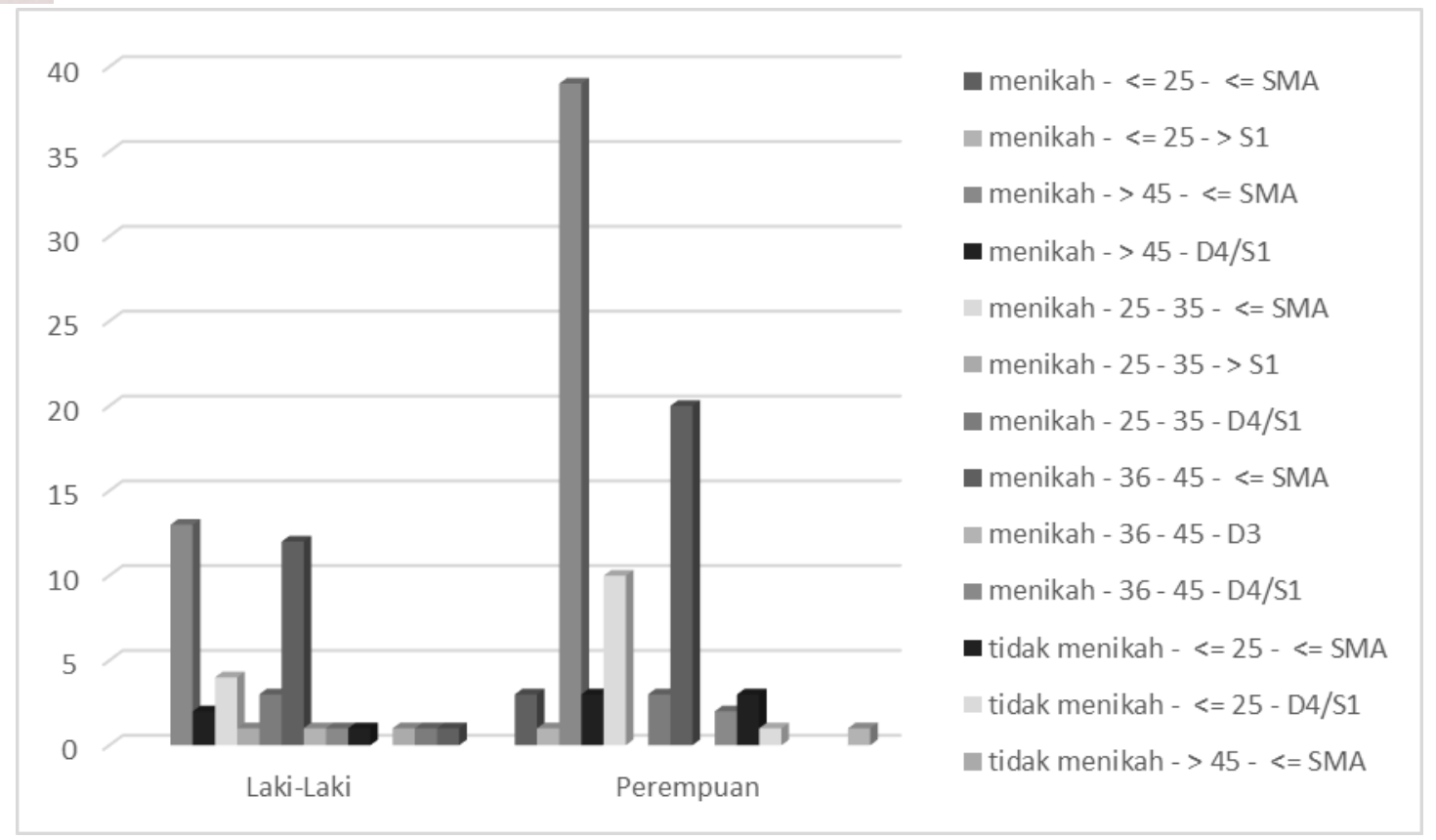

Figure 3. Profile of BPR Respondents

Source: Data processed, 2018.

Refer to Figure 3 Profile of BPR Respondents Based above, it can be seen that most of the subjects in this study were over 45 years old, $47 \%, 29 \%$ were $36-45$ years old. Followed by $17 \%$ of respondents aged between 26-35 years and the age group with the smallest percentage of those aged 25 years and under. Based on the gender of the respondents in BPR Bali Province the total respondents consisted of $68 \%$ female and $32 \%$ male.

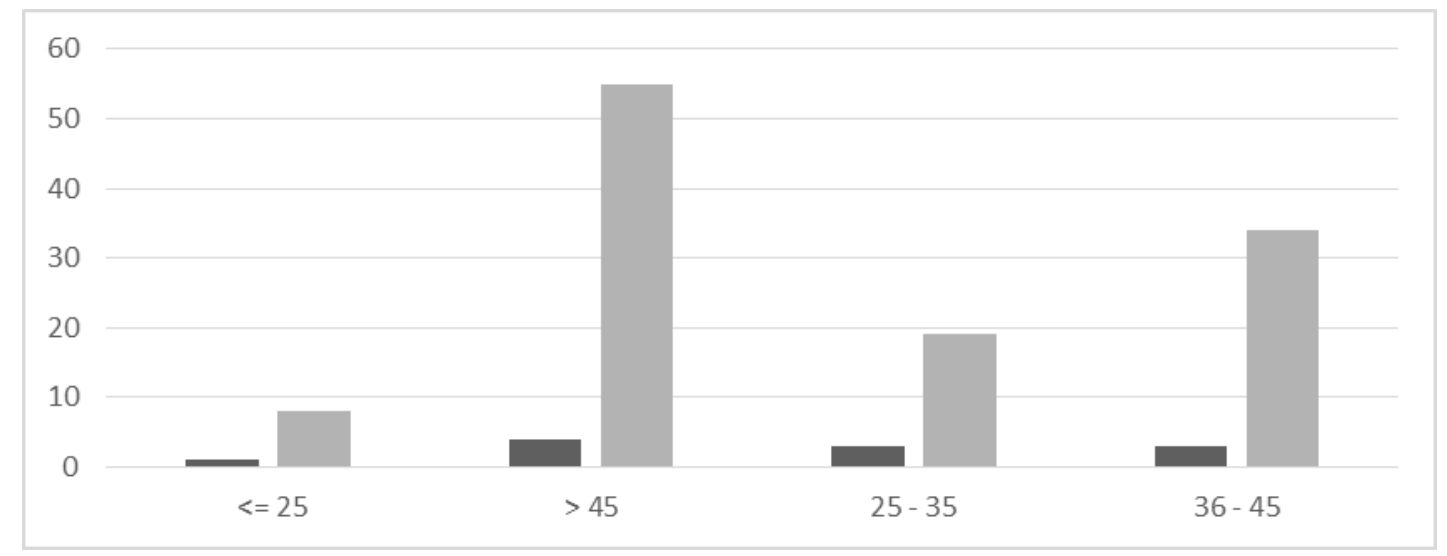

Figure 4. Comparison of the Number of BPR Customers Who Become Customers at Other BPRs and Those Who Are Not Age-Based

Source: Data processed, 2018.

Based on the above figure, it can be seen that the majority of BPR customers that are $76 \%$ of the respondents aged over 35 years. This, on the one hand can be an advantage of BPR because generally mature customers are usually quite loyal compared to young customers. This is supported by data from the table above which shows that BPR customers are quite loyal because very few customers who are customers in more than one BPRs, which is only about $10 \%$. Specifically customers older than 35 years old; customers who are customers in more than one BPRs are only around 8\%. In other words, 116 out of 127 respondents only became customers in one BPR, while 65 out of 127 respondents had accounts in more than one BPR. In 
general, in addition to carrying out saving at the BPR, the respondents also deposited their money in the cooperative and participated in social gathering. While in terms of borrowing, in addition to borrowing from BPR, customers also borrow from cooperatives, pawn shops, village credit institutions (LPD), and loan sharks.

In the other hand, BPR customers who are majority over the age of 35 can also be a threat to BPR. Furthermore, 84 out of 127 respondents aged 35 years and over were high school graduates and had not been technologically literate, so the frequency of using internet and online banking facilities was still low. Meanwhile, with the passage of time and increasingly advanced information technology, these old customers will be replaced by millennial generations who are already technologically literate. So that in order to continue to survive, BPR must always get closer to the prospective millennial.

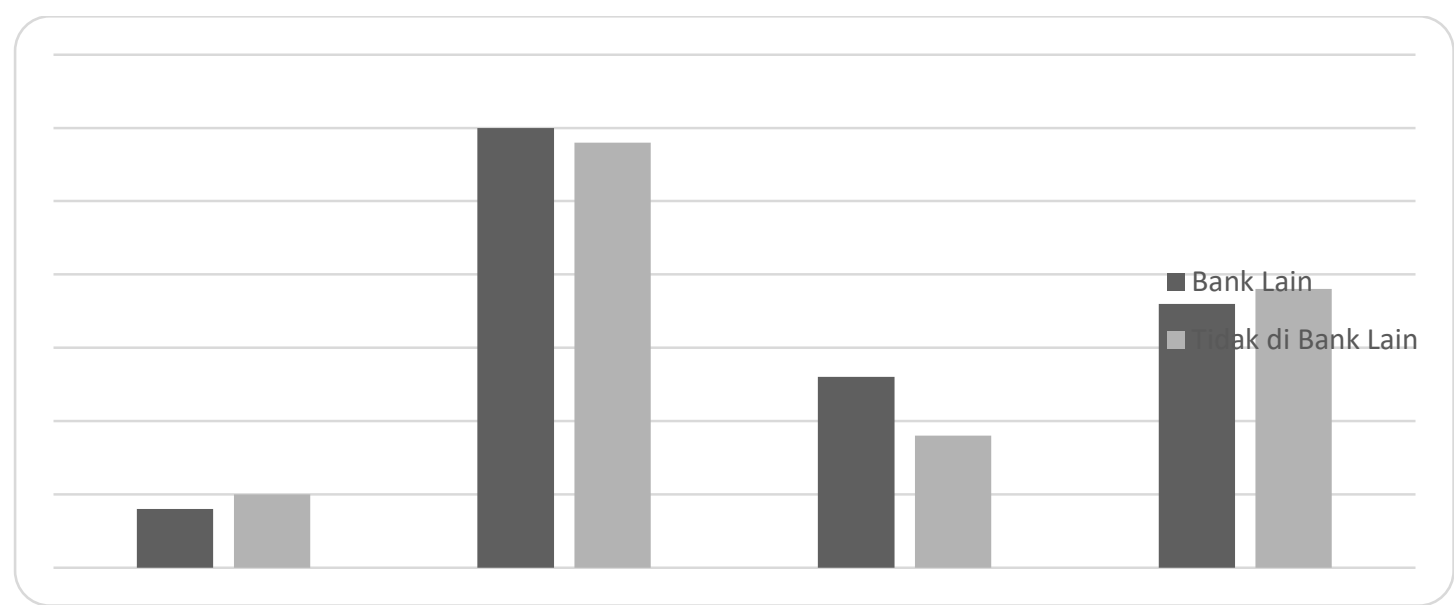

Figure 5. Comparison of the number of BPR customers who become customers at other banks and those who are not based on age.

Source: Data processed, 2018.

Tabel 4. Sequence of Perceptions of Respondents' Interest from Storage Services

\begin{tabular}{cc}
\hline & Sequence based on importance \\
\hline 1 & Employee \\
2 & Sense of Secure \\
3 & convenience \\
4 & Rereputation \\
5 & Interest \\
6 & Suitability of products with needs \\
7 & Affordability \\
8 & Facility \\
9 & Gift \\
10 & ATM \\
\hline
\end{tabular}

Source: Data processed and results of FGD, 2018.

The table above explains what factors are considered by customers when choosing a BPR to save money. Based on the results of the questionnaire, employee is the main reason for customers to choose BPR. This can be based on the ability of employees in the BPR to explain the products of the BPR so that products are easy to understand. In addition, hospitality factors have an important role in BPR services to customers. While the last factor that becomes the reason for customers to do saving is ATM. This might be based on the need for an ATM. Given that most customers choose to come directly to the BPR and make transactions both deposit and withdraw cash.

Meanwhile, when viewed from loan services, the order of the level of importance based 
on respondents' perceptions can be seen in the following Table 5.2.2:

Table 5. Sequence of Perceptions of Respondents' Interest from Loan Services

\begin{tabular}{cc}
\hline & Sequence Based on Loan Interests \\
\hline 1 & Ease of loan procedures \\
2 & Interesting interest rate \\
3 & Ease of payment procedures \\
4 & Guarantee is Submitted \\
5 & Product conformity with loans \\
6 & Percentage Ratio \\
\hline Source: Data processed, 2018.
\end{tabular}

Based on the level of customer interest in making loans to BPRs in Bali, one of the concerns of customers is the ease of lending procedures. Such as an explanation that is easily accepted by loan service employees, clear details regarding the rules that must be obeyed and others. Whereas the focus of the customers' lowest attention is the ratio of the percentage of loans customers make.

In addition, BPR should also provide services for old age savings because the market for these products is quite large. This can be seen based on data, as many as 86 respondents $(68 \%)$ from BPR in Bali are entrepreneurs, while 41 respondents are non-entrepreneurs. Entrepreneurial customers generally do not have retirement money as will be obtained by those who work as non-entrepreneurs.

In general, the reason customers choose BPR is because of their sense of security and trust, ease of service procedures, friendly, fast and competent employees, affordability of locations, and attractive interest in the BPR Bank. Meanwhile, the advantage of customers choosing BPRs is because of service / flexible procedures (customers can save at any time with the amount they can without having to queue to the Bank).

Based on the above description, a SWOT analysis (Strength, Weaknessess, Opportunity, Threats) can be carried out on BPR as follows:

\subsubsection{Strength of $B P R$}

The main strengths of BPRs based on the results of the questionnaire and FGD turned out to be on the factor of customer loyalty. Many BPR customers who have become customers for a long time and these customers are more concerned with the aspects of family and good relations, such that still become a loyal customer rather than having to move to become a customer of another bank.

\subsubsection{Weaknesses of BPR}

BPRs still cannot utilize technology optimally for the banking services offered, although there are also some BPRs that have begun to use information technology to support their business. In addition, BPR employees also generally have lower qualifications lower than qualifications of employees of commercial banks and have not been given professional training and quality services that have not been standardized.

\subsubsection{Opportunities faced by_BPR}

Opportunities faced by BPRs are actually quite large, namely BPRs can offer lower interest credit programs, additional new vehicle of credit facilities / improved service procedures that keep up with the times, improved service procedures (such as ATM facilities, gold savings and umrah savings), and also offering more products for old age savings because the majority of BPR customers are entrepreneur. 


\subsubsection{Threats faced by BPR}

The challenge faced by BPRs is to be able to provide services that reach more to the younger generation by utilizing information technology and allow among BPRs to work together and collaborate to create a joint banking service system by utilizing the internet and information technology, to reduce investment costs. As it is informed earlier, in addition to competing with commercial banks, BPR also faces competition with the emergence of fintech through its peer to peer lending. Furthermore, BPRs compete with LPDs where the LPD has a significant role in meeting the needs of citizens' funding due to the high level of Balinese public trust on cultural values.

Based on the FGD that has been conducted by presenting the management of several BPRs in Bali and with representatives from the OJK Bali there are several things that must get the attention of BPR. First, BPR must build capacity (capacity building), among others by improving the quality of human resources to maintain public trust and improve competitiveness and continue to improve the quality of BPR services. Second, BPR must develop banking infrastructure. Technology has become a necessity for BPRs to increase their competitiveness, improve efficiency, and accelerate rotation of the wheel of business, adapted to the characteristics of the business and the BPR customers. Third, socialization to the public that saving at BPR is guaranteed by LPS. At present not many people know. This deposit guarantee program needs to be known and understood by the community to provide a sense of security, calm, and certainty. Fourth, it is the responsibility of regulators to create a conducive environment for BPR growth and development through regulations that support industrial needs. Furthermore, efforts to strengthen BPR institutions must continue. OJK has issued a number of rules to strengthen rural banks that are still weak in risk management, capital, quality of human resources, and the latest related to the implementation of information technology (IT) for BPRs that are in the OJK regulation plan (RPOJK).

\section{Conclusion}

Based on the research results that have been conducted, there are several conclusions that can be taken. During the period of 2012-2016 there was a tendency of decreasing the average efficiency level of BPRs in Bali. The decrease was mainly due to the decrease in efficiency of the loans from rural banks located in areas outside Denpasar and private-owned BPRs. Whereas BPRs located in Buleleng, Karangasem and Gianyar Regencies are recorded as BPRs in the order of 1 to 3 seen from their technical efficiency during the study period. This decrease in efficiency appears to be due to the large operating costs of rural banks in carrying out their business activities, while the trend of the trend in credit interest rates is declining.

Despite this, out of 134 BPRs evaluated, there are 6 (six) banks that are continuously efficient in the five-year observation period (called super-efficient banks). Of the six banks, two came from Denpasar, two from Buleleng, one from Badung, and one from Karangasem. Amid fierce competition in the micro sector and the entry of fintech and the era of low interest rates, these BPRs are still efficient because they are supported by good infrastructure and human resources, besides the big contribution from owners.

Meanwhile, based on the results of questionnaires and FGDs that have been conducted, it can be concluded that in order to increase the competitiveness of BPRs, they must continue to improve their efficiency through product innovation by utilizing information technology and systems, increasing public trust, maintaining customer loyalty, vision and mission and networks owned by the owner, and increase networks with other banks.

\section{References}

David FR. 2013. Strategic Management, Concepts \& Cases. England: Pearson Education Limited. 
Fethi MD, Shaban M, Jones TW. 2011. Liberalisation, Privatisation, and the Productivity of Egyptian banks: A Non-parametric Approach. The Service Industries Journal. 31(7): 1143-1163.

Gardener E, Molyneux P, and Hoai NL. 2011. Determinants of efficiency in South East Asian Banking. The Service Industries Journal. 31(16): 2693-2719.

Hill CWL, Jones GR. 2010. Strategic Management Theory: An Integrated Approach. Mason: South-Western.

Hitt MA, Ireland RD, Hoskisson RE. 2015. Strategic Management: Competitiveness \& Globalization: Concepts and Cases. Eleventh Edition. Stamford: Cengage Learning.

Hoque Z, Chia M. 2012. Competitive Forces and The Levers of Control Framework in a Manufacturing Setting. Qualitative Research in Accounting \& Management. 9(2): 123145.

Infobank magazine, April Edition 2016

Kotler P, Kevin LK. 2012. Marketing Management. England: Pearson Education Limited.

Pearce JA. Robinson RB. 2015, Strategic Management: Planning for Domestic \& Global Competition. International Edition. New York: McGraw Hill.

Rangkuti F. 2006. Analisis SWOT: Teknik Membedah Kasus Bisnis. Edisi ke-14. Jakarta: Gramedia Pustaka Utama.

Porter ME. 1980. Competitive Strategy. New York: Free Press.

Sufian F. 2010. The Impact of the Asian Financial Crisis on Bank Efficiency: the 1997 Experience of Malaysia and Thailand. Journal of International Development. 22: 866889.

Suzuki Y, Sastrosuwito S. 2011. Efficiency and Productivity Change of the Indonesian Commercial Banks. Proceedings of International Conference on economics, Trade and development IPEDR vol.7. Singapore: IACSIT.

Thompson AA, Peteraf MA, Gamble JE, Strickland AJ. 2014. Crafting and Executing Strategy, The Quest for Competitive Advantage, Concepts and Cases. Nineteenth Edition. New York: McGraw Hill Education.

Wheelen TL, Hunger JD, Hoffman AN, Bamford CE. 2015. Strategic Management And Business Policy: Globalization, Innovation, and Sustainability. $14^{\text {th }}$ Edition. London: Pearson. 